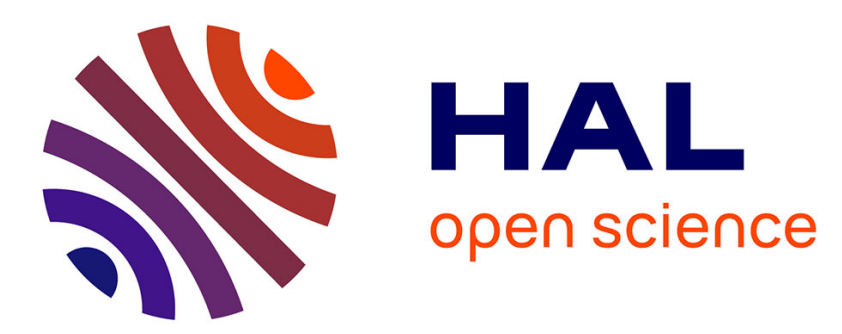

\title{
Distribution of the maxillary artery in the deep regions of the face and the maxilla: Clinical applications
}

\author{
Gaoussou Touré
}

\section{To cite this version:}

Gaoussou Touré. Distribution of the maxillary artery in the deep regions of the face and the maxilla: Clinical applications. Journal of Plastic, Reconstructive and Aesthetic Surgery, 2019, 72, pp.1020 1024. 10.1016/j.bjps.2019.02.008 . hal-03484933

\section{HAL Id: hal-03484933 https://hal.science/hal-03484933}

Submitted on 20 Dec 2021

HAL is a multi-disciplinary open access archive for the deposit and dissemination of scientific research documents, whether they are published or not. The documents may come from teaching and research institutions in France or abroad, or from public or private research centers.
L'archive ouverte pluridisciplinaire $\mathbf{H A L}$, est destinée au dépôt et à la diffusion de documents scientifiques de niveau recherche, publiés ou non, émanant des établissements d'enseignement et de recherche français ou étrangers, des laboratoires publics ou privés.

\section{다)(1) $(5$}

Distributed under a Creative Commons Attribution - NonCommerciall 4.0 International 
Distribution of the maxillary artery in the deep regions of the face and the maxilla clinical applications

\author{
Gaoussou Touré MD, PhD, FEBOMFS ${ }^{1,2^{*}}$ \\ ${ }^{1}$ Service de chirurgie maxillo-faciale, CHI Villeneuve Saint Georges, Villeneuve Saint- \\ Georges, France \\ ${ }^{2}$ Laboratoire Anatomie, URDIA, ANCRE - Université Paris Descartes, Paris, FRANCE
}

Running head: Maxillary artery distribution

\title{
* Corresponding author:
}

Dr. Gaoussou Touré, 40 allée de la source CHI Villeneuve Saint Georges 94195, France;

Email: gaoussou.toure@chiv.fr; gtoure1@gmail.com; Tel: +33 14981 25 31; Fax: +33 149

812532. 


\section{Distribution of the maxillary artery in the deep regions of the face and the maxilla - clinical applications}

\section{SUMMARY}

Composite tissue allotransplantation of the face has led to renewed interest in the vascularization of the maxilla. The maxillary artery, deep within the tissue and difficult to access, is considered to be the main artery of the maxilla. The objective of this study was to describe the distribution of the maxillary artery in the deep regions of the face and maxilla. Twenty-four maxillae were studied, 20 injected with latex and four with India ink. The maxillary artery in the pterygopalatine fossa gave rise to the sphenopalatine artery, infraorbital artery, descending palatine artery, and posterior superior alveolar artery in 24 cases. The posterior superior alveolar artery gave rise to a periosteal and intraosseous branch (in the wall of the maxillary sinus) in 18 cases. It ran mostly or fully along the osseous wall in eight and ten cases, respectively, and anastomosed at the anterior nasal spine or the infraorbital foramen. The descending palatine artery presented as a single trunk in four cases, giving rise to a greater palatine artery and a lower palatine artery in 18 cases, and four branches in two cases. Intraosseous and periosteal anastomoses were found, plus anastomosis through the incisive foramen, which was obstructed in three cases. The vascular territories were studied. The maxillary artery created an intraosseous and periosteal anastomotic network, explaining the supply pathways during different surgical procedures, risk of hemorrhage with orthognathic surgery (Le Fort type I) in a sinus lift for pre-implant surgery, and the vascular territories.

Keywords: vascularization; maxillary artery; facial transplant; maxillary sinus lift 


\section{INTRODUCTION}

Vascularization of the maxilla is characterized by its abundance and its redundancy.

The maxilla is affected in all cases of maxillofacial surgery (e.g., a sinus lift in pre-implant surgery, orthognathic surgery, zygomatic implants, and allotransplant of the face). Composite tissue transplantation has given rise to renewed interest in the study of the vascularization of the maxilla, and there are several studies in the literature that specifically examined the maxillary vasculature..$^{1-5}$

Although the various stages of removal of a graft through the middle section of the face are standard for maxillofacial surgeons, combining them to obtain a functional pedicle graft requires good knowledge of its vascularization.

The maxillary artery is the bulkiest terminal branch of the external carotid artery. ${ }^{6}$ This deep and difficult-to-access artery is considered to be the main source of the arterial vascularization of the maxilla. Despite its importance and the risk of hemorrhage in osteotomies of the maxilla and the middle section of the face, there have been few studies to date on the distribution of the maxillary artery in its pterygopalatine portion ${ }^{7}$ and inside the osseous wall of the maxilla.

Documentation of this vascularization and its variations helps to reduce the risk of hemorrhage and it provides a better understanding of the vascular supply pathways. Knowledge of the vascularization of the face is a prerequisite for devising different technical methods for harvesting grafts with reliable vascularization.

The objective of this study was to document the different modes of distribution of the maxillary artery in the deep regions of the face, the wall of the maxilla, and the corresponding vascular territory. 


\section{MATERIALS AND METHODS}

Twenty-four maxillae were studied, of which 18 were injected with latex after applying manual pressure on the common carotid artery. The remaining six maxillae were injected with India ink; three in the maxillary artery and three in the facial artery. Fifteen $\mathrm{ml}$ of ink fluid were injected progressively at a constant pressure with the aid of a syringe pump. A Le Fort type III osteotomy, sectioning of the zygomatic arch, and resectioning of the mandibular ramus were carried out.

Dissection of the external carotid artery and its branches was performed, as was dissection of the maxillary artery and its branches in the pterygopalatine fossa, followed by dissection of the periosteal and the intraosseous maxillary branches.

The principles outlined in the Declaration of Helsinki were followed. The maxillae were donated to a donation center, which operates according to the laws enforced in France. Therefore, there was no need for approval by an ethics committee for this research; respect for the donors' bodies is obligatory. 


\section{RESULTS}

In all of the cases examined, the maxillary artery in the pterygopalatine fossa gave rise to the sphenopalatine artery, the infraorbital artery, the descending palatine artery, and the posterior superior alveolar artery (Fig. 1). In the pterygopalatine fossa, the maxillary artery ran under the maxillary nerve and it gave rise the sphenopalatine artery. In one case, the maxillary artery anastomosed with the internal carotid artery through the foramen rotundum.

The posterior superior alveolar artery gave rise to a periosteal branch and an intraosseous branch, which was located in the maxillary wall (Fig. 1).

The periosteal branch anastomosed with the infraorbital artery (Fig. 2).

The branch located in the wall of the maxilla followed part of the wall in eight cases and it followed the entire wall in ten cases (Fig. 1). It spanned the entire wall of the maxilla and it anastomosed at the anterior nasal spine or the infraorbital foramen with the infraorbital artery (Fig. 1).

In one case, the intraosseous artery anastomosed with the descending palatine artery laterally in the incisive canal.

The descending palatine artery presented as a single trunk in six cases; the trunk was able to wrap around the greater palatine nerve (Figs. 3 and 4). It gave rise to a greater palatine and a lesser palatine artery in 17 cases (Fig. 5). It gave rise to four branches, one of which passed through the lateral wing of the pterygoid process in a single case. This allowed us to distinguish three types of descending palatine arteries:

- $\quad$ Type I: a single artery

- Type II: a greater palatine and a lesser palatine artery (classical form)

- Type III: more than two arteries

The sphenopalatine and the infraorbital arteries had the classical form. 
We found intraosseous and periosteal anastomoses as well as an anastomosis through the incisive foramen. The latter was obstructed in three cases.

The vascular territories corresponded to the palatine mucosa at the soft palate and the entire ipsilateral nasal cavity (Fig 6, 7). The anterior end was formed by the anterior alveolar crest on the palatine mucosa (Fig. 7), while in the nasal cavity the anterior end was formed by the posterior part of the nasal vestibule. 


\section{DISCUSSION}

The maxilla was situated in an anastomotic network created by the branches from the maxillary artery in the pterygopalatine palate. The classical periosteal branches and the intraosseous branches are integral parts of this network. ${ }^{8}$ Our study made it possible to describe, and illustrated the vascularization of the maxilla with the variations of the intraosseous artery situated in the maxillary wall and the variations of the division of the descending palatine artery.

The posterior superior alveolar artery gave rise to an intraosseous artery in 18 out of the 24 cases. This artery ran along the entire wall of the maxilla in ten cases so as to anastomose with the infraorbital artery or end at the anterior nasal spine. In eight cases, the artery only ran along a portion of the maxillary wall.

The intraosseous artery could be either short or long. In the latter case, it has been reported to anastomose with the infraorbital artery. ${ }^{8}$ This anastomosis was inconsistent in our study, in contrast to the anastomosis between the infraorbital artery and the periosteal branch of the posterior superior alveolar artery that we identified in all of our dissection cases. These results are inconsistent with those obtained by Solar et al. and Traxler et al. in their respective studies of 18 maxillae. ${ }^{9,10}$

According to our study, this intraosseous artery was inconsistent, which is compatible with clinical practice and in agreement with prior findings. ${ }^{8,11}$ We identified it in $75 \%$ of cases.

In a series of 208 maxillary sinuses analyzed by CT scan, a vascular osseous canal was identified in $55 \%$ of cases. Based on an analysis of $50 \mathrm{CT}$ scans, the authors deemed that during the surgical approach of the maxillary sinus the intraosseous artery represented a risk of hemorrhage due to its topography in $20 \%$ of cases. $^{2}$ 
The proportion of intraosseous arteries was lower based on examination of X-rays than in anatomical studies. ${ }^{8-12}$

The intraosseous artery could only be visualized when its diameter was greater than $0.5 \mathrm{~mm} .^{7}$

The lack of visualization of the vascular canal on X-rays does not exclude a risk of vascular lesion.

This intraosseous artery, rarely described in standard texts, ${ }^{4}$ participates in the vascularization of the maxilla. It warrants further investigation, particularly in implantology where it can pose a surgical risk when it has a substantial diameter and it participates in the vascularization of grafts put in place after sinus lift. ${ }^{9,10,12}$

We found that the posterior superior alveolar artery gave rise to a periosteal branch that consistently anastomosed with the infraorbitary artery.

The periosteal and intraosseous branches participated in the vascular architecture of the maxilla.

The descending palatine artery participates in the vascularization of the maxilla in the pterygopalatine fossa. It exhibited variations in terms of the number and positioning of its branches. It gave rise to between one and four branches. One of these branches crossed the lateral wing of the pterygoid process, which increases the risk of hemorrhage in the pterygopalatine disjunction. It consistently displayed an anastomosis with the ascending palatine artery, and it anastomosed with the sphenopalatine artery through the incisive foramen. This foramen was obstructed in three cases. The role of the supply of these anastomoses in vascularization has been demonstrated in several studies. ${ }^{1,2,5}$ The descending 
palatine artery lesion is not consistent during Le Fort type I osteotomy. ${ }^{5}$ Hemorrhage with Le Fort type I osteotomies most often occurs in the posterior region of the maxilla. ${ }^{13}$

Only a small number of studies to date have examined variations in the descending palatine artery due to difficulty accessing and dissecting the pterygopalatine fossa. Choi and Park have described five morphological types of distribution of the maxilla artery in the pterygopalatine fossa. $^{7}$

To our knowledge, no study has focused on the variations of the descending palatine artery in the pterygopalatine fossa and its path to the palatine mucosa.

We grouped these arteries into three types. Type III arteries gave rise to more than two branches, some of which crossed the lateral wing of the pterygoid process. Anastomosis of the descending palatine artery or its branches with the ascending palatine artery was consistent with the way it is usually described. ${ }^{6}$

These observations allow us to understand variation in the risk of hemorrhage in the pterygomaxillary disjunctions and the supply pathways in the vascularization of the maxilla in Le Fort type I osteotomies in the setting of orthognathic surgery.

The maxilla was located in an anastomotic network. This system reduces the risk of necrosis, although it increases the risk of hemorrhage.

There were adjacent mucosal vascular territories at the palatine mucosa and the nasal cavity, each corresponding to the ipsilateral maxillary artery.

We found a case of anastomosis between the maxillary artery and the internal carotid artery through the foramen rotundum. The maxillary artery gives rise to its intracranial branches through the foramen rotundum or the foramen ovale in the case of agenesis of the internal 
carotid artery. ${ }^{14}$ These anastomoses between the internal carotid artery and the maxillary artery have rarely been described. When they are functional, they ought to perhaps be considered as a supply pathway in the case of thrombosis of the internal carotid artery and they should be added to the numerous causes of neurological complications in pterygomaxillary disjunctions in orthognathic surgery. ${ }^{14}$

In this study we characterized the intraosseous artery in the wall of the maxilla, the variations of the descending palatine artery in the pterygopalatine fossa, and the palatine and nasal mucosa arterial territories of the nasal cavity.

This architecture of the arterial vascularization reveals the role of the maxillary artery and its branches, and it supports the notion that it can be removed with the middle third of the face for composite tissue allotransplantation of the face. ${ }^{4,15,16}$

However, the maxillary artery is a deep artery that is difficult to access, and its removal as part of composite tissue allotransplantation of the middle section of the face is not necessary in practice. ${ }^{17,18}$ A detailed study of the vascularization of the middle section of the face is of primary importance for research and the teaching of reliable and reproducible procedures. The low number of cases of allotransplantation of the face that are carried out, and the constraints relating to graft harvesting, underscore the importance of anatomical research. Different methods of removal need to be devised in order to allow grafts with optimal vascularization to be obtained. 


\section{Conflict of Interest}

None.

\section{Funding Source}

No specific funding was received for this study. 


\section{REFERENCES}

1. Bell WH, Fonseca RJ, Kenneky JW, Levy BM. Bone healing and revascularization after total maxillary osteotomy. J Oral Surg 1975;33:253-60.

2. Bell WH, Schendel SA, Finn RA. Revascularization after surgical repositioning of one-tooth dento-osseous segments. J Oral Surg 1978;36:757-65.

3. Siebert JW, Angrigiani C, McCarthy JG, Longaker MT. Blood supply of the Le Fort I maxillary segment: an anatomic study. Plast Reconstr Surg 1997;100:843-51.

4. Gauthier A, Lezy JP, Vacher C. Vascularization of the palate in maxillary osteotomies: anatomical study. Surg Radiol Anat 2002;24:13-7.

5. Toure G, Meningaud JP. Anatomical study of the vascular territories of the maxilla: role of the facial artery in allotransplantation. J Plast Reconstr Aesthet Surg 2015;68:213-8.

6. Standring S. Gray's Anatomy: The Anatomical Basis of Clinical Practice. 40th ed. Edinburgh: Churchill Livingstone Elsevier, 2008.

7. Choi J, Park HS. The clinical anatomy of the maxillary artery in the pterygopalatine fossa. J Oral Maxillofac Surg 2003;61:72-8.

8. Ella B, Sedarat C, Normand E, et al. Vascular connections of the lateral wall of the sinus: surgical effect in sinus augmentation. Int $\mathrm{J}$ Oral Maxillofac Implants $2008 ; 23: 1047-52$.

9. Solar P, Geyerhofer U, Traxler H, Windisch A, Ulm C. Blood supply to the maxillary sinus relevant to sinus floor elevation procedures. Clin Oral Implants Res 1999;10: 3444.

10. Traxler H, Windisch A, Geyerhofer U, Surd R, Solar P, Firbas W. Arterial blood supply of the maxillary sinus. Clin Anat 1999;12:417-21. 
11. Mardinger O, Abba M, Hirshberg A, Schwartz-Arad D. Prevalence, diameter and course of the maxillary intraosseous vascular canal with relation to sinus augmentation procedure: a radiographic study. Int J Oral Maxillofac Surg 2007;36:735-8.

12. Elian N, Wallaces S, Cho SC, Jalbout ZN, Froum S. Distribution of the maxillary artery as it related to sinus floor augmentation. Int $\mathrm{J}$ Oral Maxillofac Implants 2005;20:784-7.

13. Regan BO, Bharadwaj G. The identification and protection of the descending palatine artery in Le Fort I osteotomy: a forgotten technique? Br J Oral Maxillofac Surg $2007 ; 45: 412-4$.

14. Damry N, Hanquinet S, Christophe C, Janssen F, Delatte P, Perlmutter N. Bilateral congenital absence of the internal carotid artery with a primitive transmaxillary arterial anastomosis. Pediatr Radiol 1994;24:200-3.

15. Yazici I, Cavusoglu T, Comert A, et al. Maxilla allograft for transplantation: an anatomical study. Ann Plast Surg 2008;61:105-13.

16. Banks ND, Hui-Chou HG, Tripathi S, et al. An anatomical study of external carotid artery vascular territories in face and midface flaps for transplantation. Plast Reconstr Surg 2009;123:1677-87.

17. Meningaud JP, Hivelin M, Benjoar MD, Toure G, Hermeziu O, Lantieri L. Procurement of total human face graft for allotransplantation: a preclinical study and the first clinical case. Plast Reconstr Surg 2010;126:1181-90.

18. Pomahac B, Lengele B, Ridgway EB, et al. Vascular considerations in composite midfacial allotransplantation. Plast Reconstr Surg 2010;125:517-22. 


\section{FIGURE LEGENDS}

Figure 1: The left maxillary artery: distribution of maxillary artery in the pterygopalatine fossa and to the maxilla. 1: Maxillary artery, 2: Infraorbital artery, 3: Sphenopalatine artery, 4: Descending palatine artery, 5: Posterior superior alveolar artery, 6: Intraosseous branch of the posterior superior artery, 7: Periosteal branch, 8: Maxillary sinus membrane.

Figure 2: The left maxilla. ION: infraorbital nerve. IOA: infraorbital artery. 1: Posterior superior alveolar artery - periosteal branch.

Figure 3. The right maxilla. 1: The descending palatine artery twists around the greater palatine nerve, 2: Infraorbital artery and infraorbital nerve, 3: Pterygoid process.

Figure 4: The right maxilla. 1: Descending palatine artery in pterygopalatine groove: greater and lesser palatine artery, 2: Greater palatine nerve, 3: Pterygoid process.

Figure 5: The left pterygopalatine fossa. 1: Maxillary artery, 2: Infraorbital artery, 3:

Sphenopalatine artery, 4: Descending palatine artery, 5: Posterior superior alveolar artery, 6: Lateral plate of the pterygoid process, 7: Medial plate of the pterygoid process.

Figure 6: Absence of incisive foramen.

Figure 7: The right nasal cavity. In black: the territory of the maxillary artery-in red: the territory of the facial artery. The walls are vascularized by the maxillary artery - the vestibule of the nasal cavity by the facial artery. A: Lateral wall of the nasal cavity, B: Medial wall of the nasal cavity. 1: Sphenoidal sinus, 2: Middle turbinate, 3: Semilunar ostium, 4: Inferior turbinate, 5: Nose hairs and vestibule. 


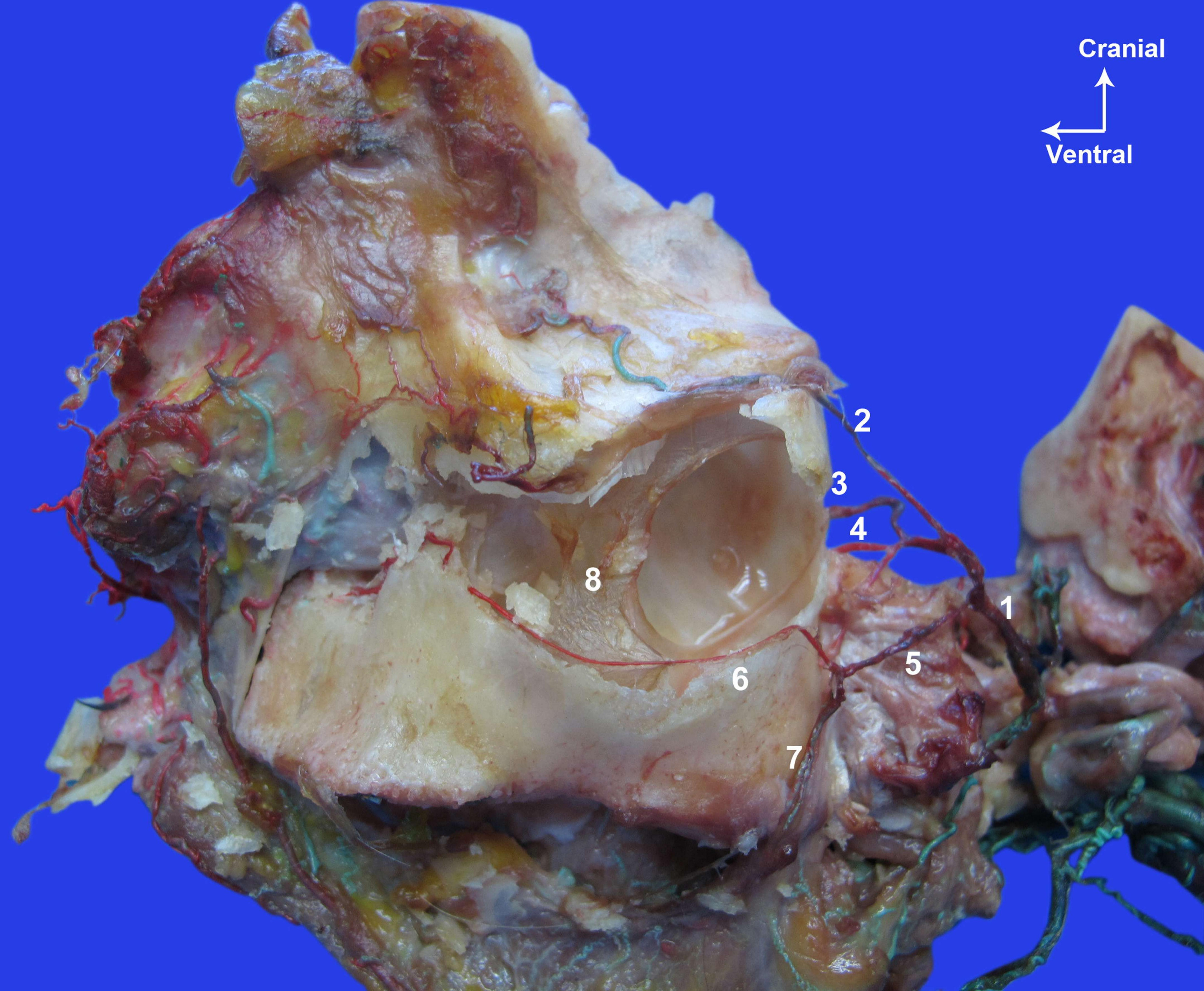




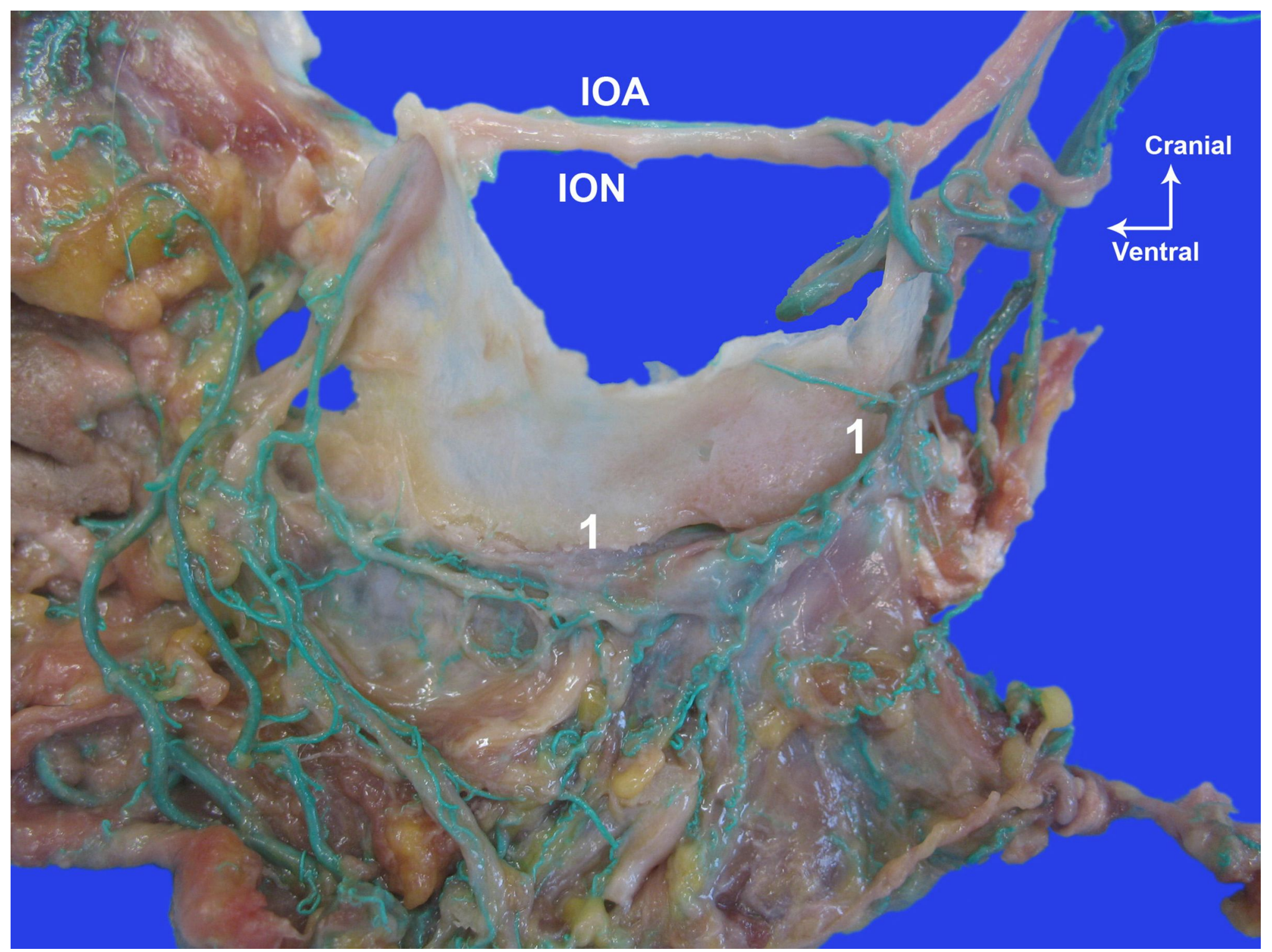




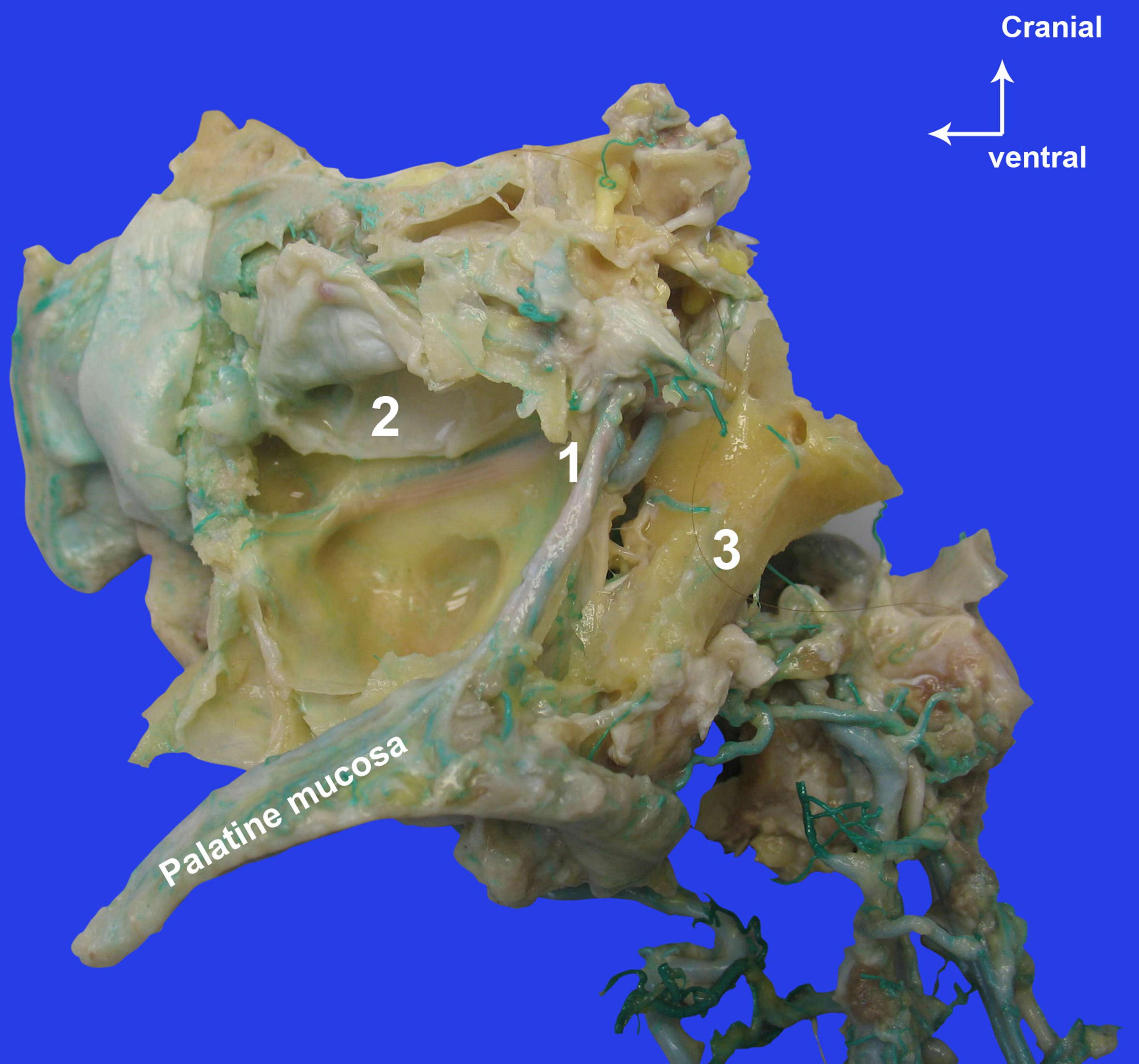




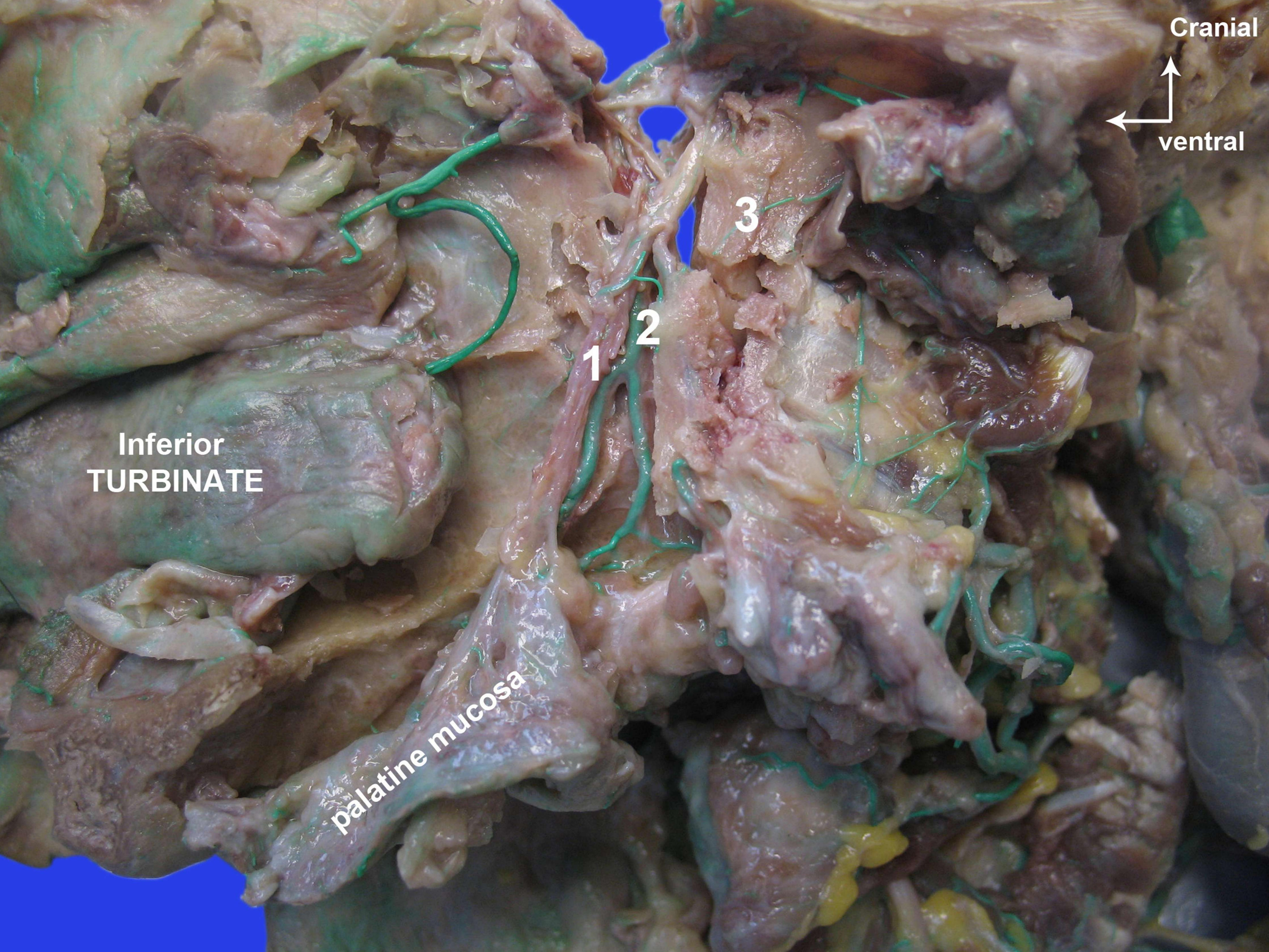




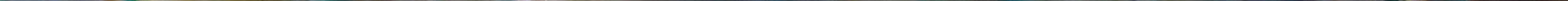



A

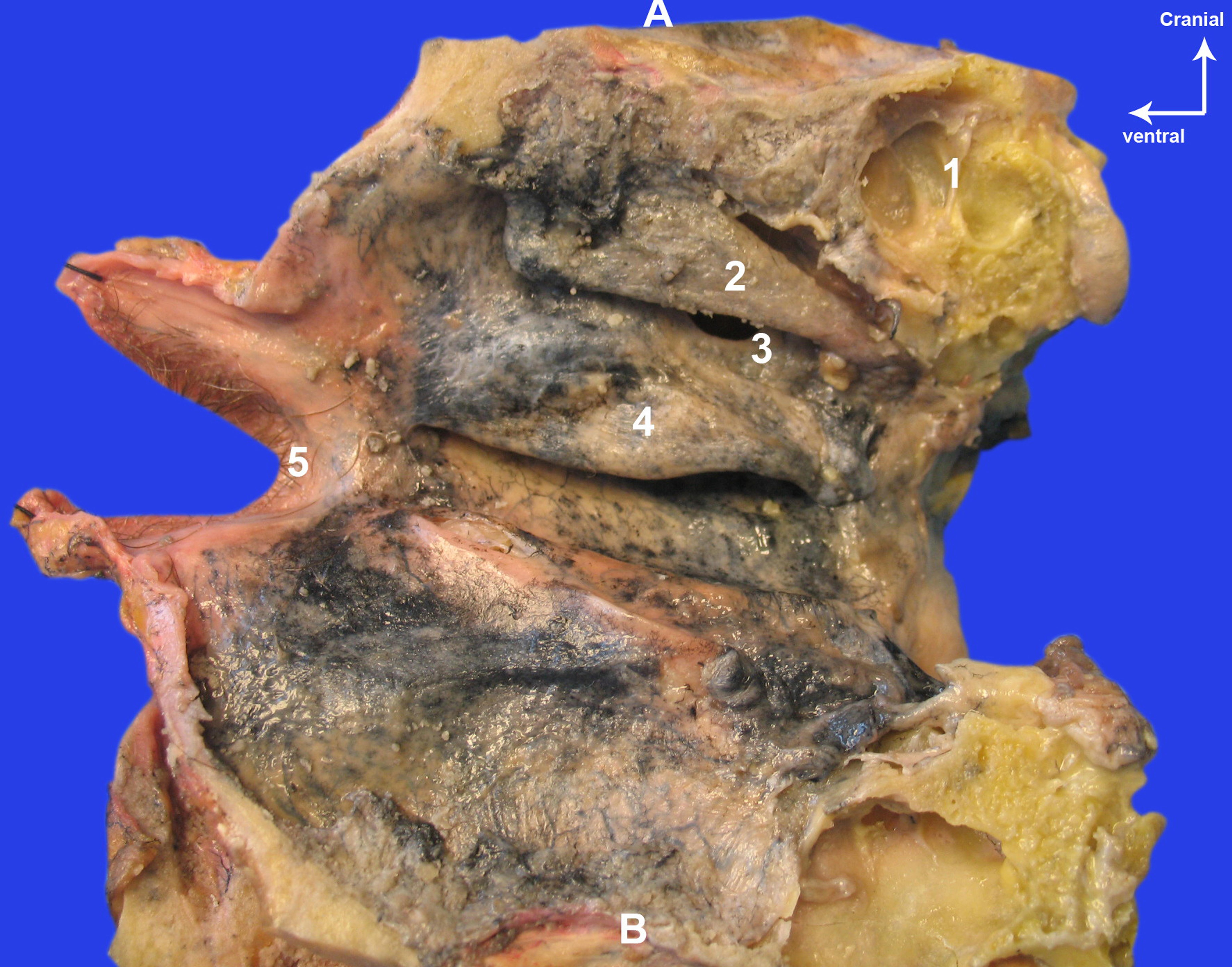

